\section{WESTERN HOSPITAL.}

MR. TAUMAN'G REPLY TO MR. SLETGH.

\section{To the Editor of The LanceT.}

Sir,-Mr. William Willcox Sleigh, in a letter headed, "Reply to Mr. Brodie," has broken out into a most violent philippic ayainst me and Dr. A yre A.t first it appears extraordinary that Mr. Sleigh should seek to wreak his vengeance on me, for I solemnly declare I never even saw Mr. Brodie's letter till it appeared in your Journal. But you must not be allowed to remain ignorant of the cause which has brought down the wrath of this medical agitator on my head. Some few weeks back, certain awkward charges were preferred against Mr. Sleigh, in the committee of this hospital, respecting transactions between Mr. Sleigh and Mr. Buchanan, when $I$ and Dr. Ayre expressed our indignation and disgust at Mr. Sleigh's conduct towards MIr. Buchanan; this explains the cause of the breach between us. Mr. Sleigh fancied Mr. Brodie's letter would lead to an exposure of his virtuous conduct, and therefore, in the true spirit of his unparalleled impudence, determined on publishing a statement, which he vainly flattered himself might shield him from the ignominy that awaited him ; and this statemeut he put forth in the shape of a reply to Mr. Brodie. Mr. Sleigh has endeavoured to throw an imputation on $\mathrm{Mr}$. Brodie's character, by publishing his most unwarrantable certificate to that gentleman; but now the source is known from which it proceeds, such a document will never injure Mr. Brodie, and I have great pleasure in stating that $I$ have always found Mr. Brodie a most indefatigable student, and a highly honourable young man.

In the fury in which Mr. Sleigh writes, he accuses me and Dr. Ayre of having offered "Mr. Pink a thousand pounds to get him ont of the hospital ;" this, certainly, is the most farcical part of the whole letter! for had we chosen to have given Mr. Sleigh the twentieth part of that sum he would joyfully have accepted the offer, and resigned all connexion with the hospital forthwith.

Next, it is most unblushingly asserted, that we offered to purchase some of the hospital premises from Mr. Cox. In reply to this barefaced falsehood, I beg to refer you to the following letter which I obtained from Mr. Cox the day before yesterday.

“ No. 2, Portwan Street, Jan. 2, 1829.

"Sir,-I beg to state that I never had any offer from you, or Dr. Ayre, to purchase the premises belonging to $M$ r. Vincent, (for whom I am agent,) which form a part of the Royal Western Hospital. "Your obedient servant, “J. Cox.

To M. Truman, Esq.

Mr. Sleigh is not an individual who hides his talents under a bushel, and therefore he takes care to avow himself the illustrious founder of this hospital, and to blazon forth his responsibility of twelve thousand pounds. I think you will smile, when you learn that, to eke out this sum, Mr. Sleigh has reckoned up the rent of the premises for the next forty years; and that, so far from being a loser by the hospital, he has not very indirectly made some thousand pounds by it. There are other circumstances which, at present, 1 am not at liberty to disclose, but which will shortly be published, and then Mr. Sleigh's real situation with respect to the hospital will be shown, and the gross deception exposed, which he attempts to practise on the public, by recklessly stating he is the only individual who has mainly contributed to its support.

In explanation of my not having retired with Dr. Ayre from the hospital, I beg to state that I did not consider I was called upon to leave an institution in which $I$ am greatly interested, on account of Mr. Sleigh's misconduct; besides, I considered it would be ceding too great a triumph to that individual, as I well knew he wished me and MIr. Buchanan to resign, that he might have an opportunity of raising money by procuring other partners and demonstrators. Indeed, this has been proved in the sequel, for Mr. Sleigh boasted he would get me turned out of the hospital, and has, since Dr. Ayre's retirement, exerted himself to the utmost to accomplish that object, but without success.

I shall now conclude, as I'flatter myself I have completely contradicted the gross falsehoods asserted by Mr. Sleigh, and added another record to the many that exist of that individual's amiable nature; perhaps I have been wrong in taking any notice of his letter, as I am well aware of the great esteem the profession have for Mr. Sleigh's character.

\section{I am, Sir,}

Your most obedient servant, Matrhaw Truman. 14, Park Place, Jan, 4, 1830.

DR. AYRE'S REPLY TO MR, SLEIGH.

\section{To the Editor of THE LANCET.}

Sir.-The letter addressed to you by Mr. Sleigh, and published in your LanceT of this week, has imposed upon me the painful but necessary duty of submitting to your 